者らはすで代ての様な考え方に立っで；力学的性筫之材 質の不均質を有する溶接部での破罗クライテリアに関す 当検討を行ならでり：ぞの詳細门りいては次報以下で 報告す当

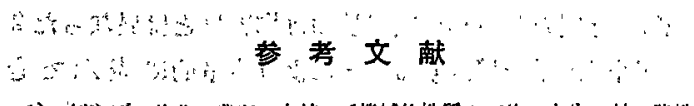

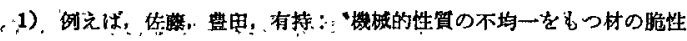

破烄举野”日本造船学会諭文集第134号 (1973)，425

2) British Standard Institution: "Methods for Crack Opening Displacement (COD) Testing", DD19, 1972

3）住友金属：“住友の低温用 $9 \% \mathrm{Ni}$ 鋼板とその溶接について”

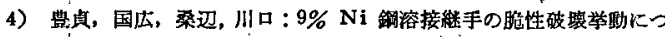
认で日本造船学会䇶交集 第138号 (1975)，434

5) British Standard Institution: "Methods "for Crack Opening Displacement (COD) Testing", BS5762, 1979

6）例之ば，金沢，町田，萩原：“工莱的訊験法としての曲げ COD 武 凂についで日本造船学会略交集第132号 (1972)，361

in

\title{
力学的性質の急変部に切欠きをもつ材の塑性 変形挙動とき裂開口変位*
}

\author{
佐藤邦彦**, 豊田政男 $* *$, 南二三吉**，佐藤 進***，中西睦夫****, 有持和茂**** \\ Crack Tip Plastic Deformation of Notched Plates with \\ Mechanical Heterogeneity*
}

by Kunihiko Satoh**; : Masao Toyoda**, Fumiyoshi Minami**, Susumu Satoh***, Mutsuo Nakanishi**** and Kazushige Arimochi****

\begin{abstract}
Fracture performance of welds is influenced by mechanical and/or metallurgical heterogeneity caused inevitably in the welded joint. In the present paper, consideration has been carried out of plastic deformations and crack opening behaviors of cracked welds with mechanical heterogeneity, in particular, in surength. Finite element analyses based on elasto-plastic theory have been conducted for overmatched and undermatched weld joints with crack existing along fusion line under tension or bending.

A considerably unsymmetrical plastic behavior is observed in the notched welds with heterogeneity in strength. "'Accordingly, the plastic behavior results in unsymmetriccal crack opening. As the degree of unsymmetrical opening s affected by the strength ratio of weld metal to base metal, the total opening displacement calculated from global COD does not necessarily control deformation of each material in the vicinity of crack tip. The local COD defined in the present paper may become an appreciate measure of deformation of crack tip as same in homogeneous material, exclusive of the part of which strength level is considerably higher than that of other vart.
\end{abstract}

1. 緒 言

溶接部の破壊性能を考えるとき，溶接部に不可避的に 存在する巨視的な力学的不均質性の影響を無視するとと ができない，その極端な例として，著者らは前報1，保 抒いて，オーステナイト系溶接材料を用いた: $996 \mathrm{Ni}$ 鋼

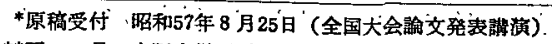

**正具，大阪大学工学部 Member, Faculy of, Engineering, O'saka University

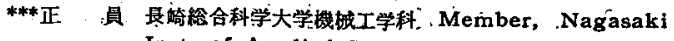
Inst. of Applied Science

*****正 員 住友金属工䅈(株) Mèmbèr, Sumitómo Métal Ińdustries, itd.
}

溶接継手を取り上げ，といに 3 点曲げ COD 試験におけ る破壊䩓性評価手法について問題提起を行った，前報” に示したように，力学的性質が急変する部分飞切久きを あつ材では均質材とは著しく異なる変形挙動を示すた め，乙のような場合の破壊強度の評洒の仕方は，自ずか ら均質材の場合とは異なるととが予想される.すなわ ち, 従来の多くの破壊性能評価が主に均質材を対象とし たものであるととを考えれば，不均質性をもつ材の破壊 性能評価を明ら汃するととは，溶接部の性 能評価に とって不可欠である.

本報は以上のような問題提起に基つき，まず強度の不 

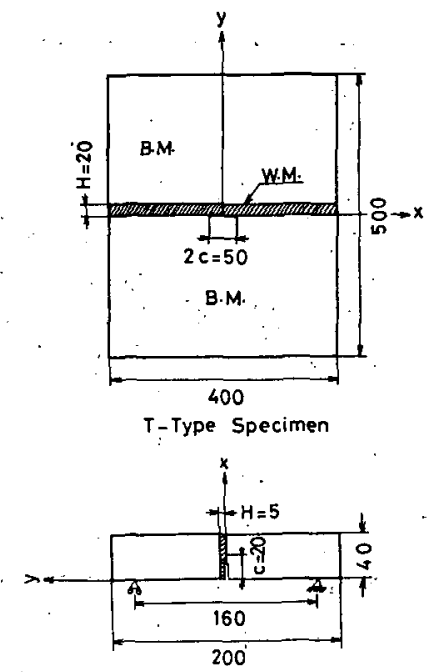

B-Type Specimén

Fig. 1 Design for notched-specimen subjected to tension or bending.

均一をむつ場合を注目し，その強度の急変部に切欠きを あつ材の変形举動を明らか汇するとと屯に; 切欠き材の 变形への力学的不均質性の影響基礎的な立場加引把握

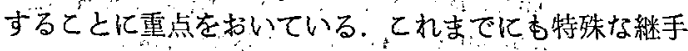
を対象とした解析例2 は見られるが，本報のようにより 一般的な強度の不均一度合住対して検討を行い，き裂先 端近傍の市力・歪特性の支配パラメータに関して考察を 加えたあのは見当らない.本報ではまず基本的な場合々 して，引張りおよび曲げを受りる継手を取り上げ，溶接 金属と母材の強度が異なり，その融合線化沿って切欠き を委つような模型的な継手を対象として，その変形挙動 孝有限要菜法（以下 FEM 之略す）を用いた弹塑性解析 により検討を加えた。，とくに，望性域の進行やき裂開口 挙動比注目し，き裂先端変形量に対するき裂開口茬の指 標性に関して検討を試みる.

\section{2. 解析対象亡条件}

解析対象として Fig：！示すような引張型試験片（T- type)と 3 点曲げ試験片(B-type)の 2 種類を取り上げた. いずれす継手の融合線を境しして母材 (B.M.) と溶接 金属 (W. M.) の強度が急変しているあの之する! T“ type は, 切欠き長さ $2 c=50 \mathrm{~mm}$, 板幅 $W=400 \mathrm{~mm}$; 溶接金属部幅 $H=20 \mathrm{~mm}, \mathrm{~B}$-type $40 \mathrm{~mm}, H=5 \mathrm{~mm}$ である（切欠きは crack を想定して おり，先端では切欠き幅は零)。(解析の対象之した母材 と溶接金属部の力学的性質は Table 1 亿示す通りで, 母材はすへて同一として溶接金属と母材の降伏応力 $\sigma_{Y}$ の比（以下 $S_{r}$ と記す）を0.5 1.50範国で変化させて あり，均筫材を含め各 type 上屯に5 系列の組合せを採 用した。(例えば表中の試験片記号 TA 80-40は，母材 および溶接金属の降代沈力がそれでれ $80 \mathrm{kgf} / \mathrm{mm}^{2}, 40$ $\mathrm{kgf} / \mathrm{mm}^{2}$ の引張型試験片であるととを表わしている). また解析には，それぞれの材料が指数硬化則に従う相当 応力 $\sigma$, 相当塑性歪 $\bar{\varepsilon}_{p}$ 関係をむつむのとし，

$$
\tilde{\sigma}=C\left(\alpha+\bar{\varepsilon}_{p}\right)^{n}=\sigma_{Y}\left(1+\bar{s}_{p} / \alpha\right)^{n}
$$

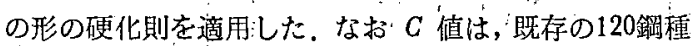
の資料を基に決定し， $n$ 値は，構造用鋼の実績を基にし て $n \sigma_{Y}=7.0$ と方した。 また材料の維弾性係数 $E=21000$ $\mathrm{kgf} / \mathrm{mm}^{2}$, ポアリン比 $\nu=0.3$ は全で一定である。

以上の条件下で定ひずみ三角形要素による2瓷元 FEM 弹塑性解析 (平面応力状態) を行った。，切欠先 端近傍の最小要素寸法は: 0.01 mm である。降代条件に は等方性材料に対する Mises の降伏条件を用いた。 また 解析にあたっては；切㰥き先端还傍の要素の $\bar{\sigma}, \bar{\varepsilon}_{p}$ の 值が所定の $\bar{\sigma}-\bar{\varepsilon}_{p}$ ，関係からはずれないように負荷橧分を 調整し，そのような所定の $\bar{\sigma}-\bar{\varepsilon}_{p}$ 関係を潇足する負荷範 国内を本報での検討詨象とした。

\section{3. : 不均質材における塑性変形の進行}

Fig. 2-a は，引張型嘕験片のネ.\%ト継面応力 $\sigma_{N}$ と標 点距離 $500 \mathrm{~mm}$ 關の平均ひずみ $\varepsilon$ の関係を示したもの である。降代強度比 $S_{r}<1.0$ の継手（軟質溶接継手） では，均哲盘材 TA 80 立り香低い荷重で伸びが大き なり，办小さい程との傾向が著しい， $s_{r}>1.0$ の継手

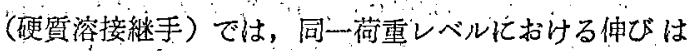

Table 1 Mechanical Properties of Materials Used for FEM Analyses.

\begin{tabular}{|c|c|c|c|c|c|c|c|c|c|c|}
\hline \multicolumn{2}{|c|}{ Specimen Series } & \multicolumn{4}{|c|}{ Base Metal } & \multicolumn{2}{|r|}{ Weld } & \multicolumn{2}{|l|}{ Metal, } & \multirow{2}{*}{$\begin{array}{c}S r \\
\left(\sigma_{y}^{w} / \alpha_{y}^{g}\right)\end{array}$} \\
\hline T-Type & B-Type & $a^{8}$ & $c$ & $\alpha$ & $n$ & $\sigma_{Y}^{w}$ & $c$ & $\alpha$ & $n$ & \\
\hline TABO : & $B A B 0^{\circ}$ & 80 & $i 12.8$ & 0197 & 0.0875 & - & - & $\div$ & - & 1.0 \\
\hline TABO-40 & $B A 80-40$ & 80 & 112.8 & 0.0197 & 0.0875 & 40 & 86.2 & 0.0124 & $0: 175$ & 0.5 \\
\hline TA80-60 & $B A 80-60$ & 80 & 112.8 & 0.0197 & 0.0875 & 60 & $95: 1$ & 0.0196 & 0.117 & 0.7 \\
\hline TA80-100 & BABO-100 & 80 & 112.8 & & 0.0875 & 100 & 132.2 & 0.0186 & 0.070 & 1.25 \\
\hline $80-120$ & & 80 & 112 & & & 120 & {$[151.4$} & 100 & 505 & \\
\hline
\end{tabular}

-1) $\sigma_{r}:$ Yield Stress (kg $\left.t / \mathrm{mm}^{2}\right)$ 


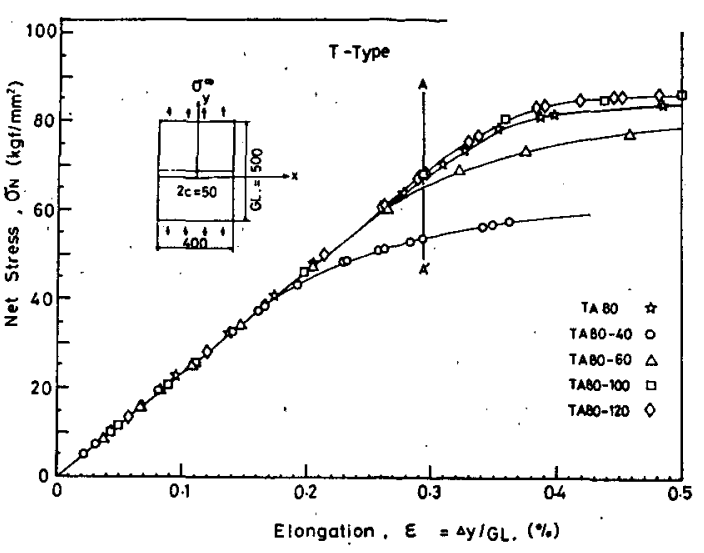

(a) Relationship of net stress $\sigma_{\bar{N}}$ versus elongation in percent $\varepsilon$ (G.L. $=500 \mathrm{~mm}$ ).

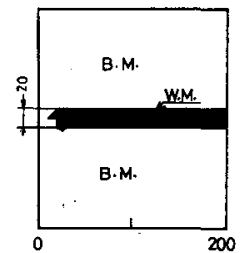

TA $80-40$

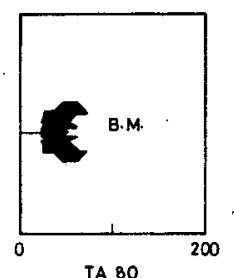

TA 80

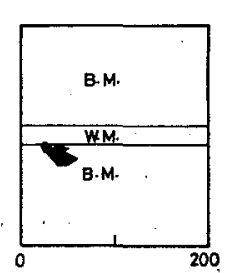

TA BO -120 (b) Plastic zone ahead of crack tip when $\varepsilon$ is constant $(\varepsilon=0.29 \%)$.

Fig. 2 Global deformation behaviors of both homogeneous and heterogeneous notched-plates subjected to tension.

均質母材よりやや小さいが，解析範囲の $\varepsilon \leq 0.5 \%$ \%では $S$ ，の影嚮は認められない，軟躓継手 (TA 80-40), 均質 母材, 硬質継手 (TA 80-120) それぞれに対し，因中の $\mathrm{AA}^{\prime}$ の状態 $(\varepsilon=0.29 \%)$ におりる切久き先端近傍での 塑性域の搪がり方を示すと Fig. 2-b のようである. $S_{r}<$ 1.0 の軟質継手では軟質部材が full yield に達するまで は母材部の塑性変形はそれほど進展しないが2)，S，が 1 に近つくにつれて母材部での塑性域む拡大するようにな る. 一方 $S_{r}>1.0$ の硬質継手では，溶接金属部の塑性域 は極めて小さく, 特に降伏強度比 $S_{r}$ が大きい之高負荷 段階においては, 溶接金属部での塑性变形がそれほど進 行していないのに，切欠きを有していない母材側におい ても融合境界部から飛び石状に塑性変形が進展し始める 場合がある.とのように力学的不均質性を有する材にお りる塑性変形挙動は, 切欠き長さや溶接金属部幅が二定 であ降状応力比 $S_{r}$ によって大きく異なる。

各負荷段階におりる力学的状態量亡して切欠き先端近 傍の荷重方向応力 $\sigma_{y}$ や相当塑性歪 $\bar{\varepsilon}_{p}$ に注目し, 力学 的不均質性を有する切欠き材におりる塑性域の搪大の仕 方を分類すると Fig. 3 のようになる。四中の綎軸，横軸

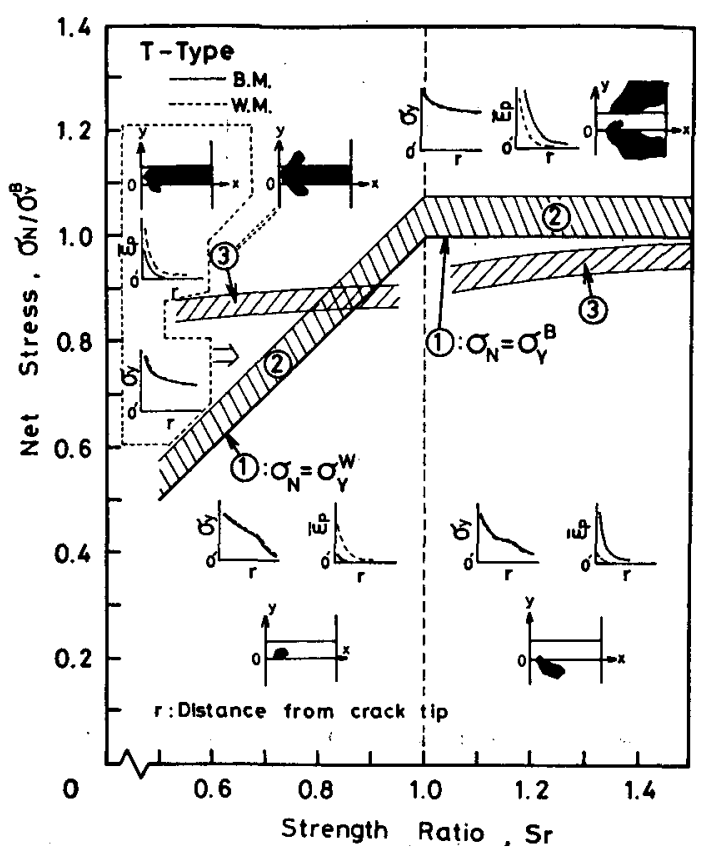

Fig. 3 Extension of plastic deformation of notchedplate with mechanical heterogeneity, with particular reference to vertical stress $\sigma_{y}$, equvalent plastic strain $\bar{\varepsilon}_{p}$ and plastic zone.

はとあに母材の降伏応力 $\sigma_{Y}{ }^{B}$ で無次元化しており，直 線 (1) は塑性拘束がない場合の full yield 曲線を示して いる. 負荷応力の增加に伴う変形の進行の仕方の分類は 軟質 $\left(S_{r}<1\right)$ 加硬質 $\left(S_{r}>1\right)$ 杹よって次のようにな る.

$S_{r}<1$ の場合，母材による塑性拘束のために直線 (1) では full yield に至らず，それよりも少し大きな負荷レ ベルになって溶接金属のみがネット断面降伏する，解析 では (2) の斜線の範囲で full yield しており，そのとき の $\sigma_{N}$ の值は傾向的には $S_{r}$ が小さいほど (2) の斜線の 上限に近くなる。また曲線（3) を超える負荷応力レベル になると図中に示すように溶接金属部を越えて母材側に も塑性域が広がりはじめる。乙の場合 $S_{r}$ が1に近つく と，溶接金属が full yield するよりあ先に溶接金属を越 えて塑性域が母材に広がり，その後溶接金属のみが full yield するような挙動を示す.

一方 $S_{r}>1$ の場合には塑性変形は負荷応力が曲線 (3) の值を超えると硬い溶接金属を越えて飛び石状の塑性域 の拡がりを示し，そして直線 (1) の $\sigma_{N}=\sigma_{Y}{ }^{B}$ を少し超 えた荷重レベル（2）の領域）で母材側で full yield に 達する。乙のときの $\sigma_{N}$ の值す切欠きの存在による塑性 拘束のため (1) よりは多少大きくなる. 
塑性域の広がり方の以上のような特徵に対応して，応 力・ひずみ分布む次のようになる.引張方向の応力 $\sigma_{y}$ のき裂線上の分布は，いずれの場合に扔いてす母材，溶 接金属両領域とあほとんど差が認められないが，ひずみ 分布はき裂線上の両側で大きな差がみられる．図中に表 示するように $S_{r}<1$ の場合には硬い母材側の, $S_{r}>1$ の場合には同じく硬い溶接金属側のひずみが，強度の低 い領域に比へて著しく小さく、ひずみ集中が小さくなっ ているのが大きな特徵といえる。

\section{4. き裂開口举動}

本 FEM 解析では塑性変形の進行に上る切久き先端の 鈍化などに起因するき裂進展は考虑していないために， 切久き先端の COD は常に零であり，また本解析対象の ようなものではき裂線に対して非対称な塑性域の広がり 方（Fig. 2 (b)）を呈し，後に図示するように非対称なき 裂開口挙動を呈する。そのような場合に治従来よく行わ れているき裂先端から一定の距離の位置の開口量をとる などの手法には問題があることあ予想される．そてで切 欠き上下縁の切欠き先端近傍の塑性域の拡がりが, 切欠 き前縁のストレッチ・ゾーン幅に対応するもののと考え て，切欠き上下縁の切欠き先端近傍の弾塑性境界部にお ける開口量を COD と定義し， $\delta_{s p}$ で表わすととにす $3^{4)}$.

このように定義した $\delta_{e p}$ の妥当性を調へるため，一 様引張りを受ける均質材について上に定義した $\delta_{e p} \cdot$ と 従来加ら厸く適用されている Dugdale Model により得 られる切欠き先端 COD， $\delta$ Dugdale と比較してみると Fig.4-a のようになる。なお図には参考のため，切欠き

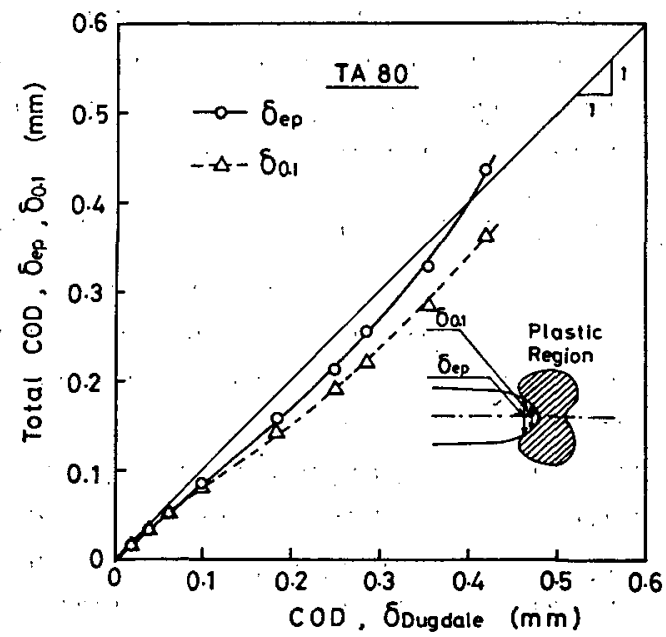

(a) in case of homogeneous notched-plate subjected to tension.
先端から $0.1 \mathrm{~mm}$ 内側の位置での COD, $\delta_{0.1}$ あ同時 に示した。一方, 3.点曲げ COD 試験片 (B-type) に ついてあ同様に $\delta_{\theta p}, \delta_{0.1}$ を求め, 従来均質材に対し て適用されている BSI の評価式》から得られる切欠き 先端 COD， $\delta_{\mathrm{BS} 5762}$ と比較すると Fig.4-b のように なる，とれらの図から判断すると，本報で定義した弾塑 性境界での COD， $\delta_{e p}$ を，負荷様式によらず切欠き先 端 COD として代用してもは浪よさそうである。

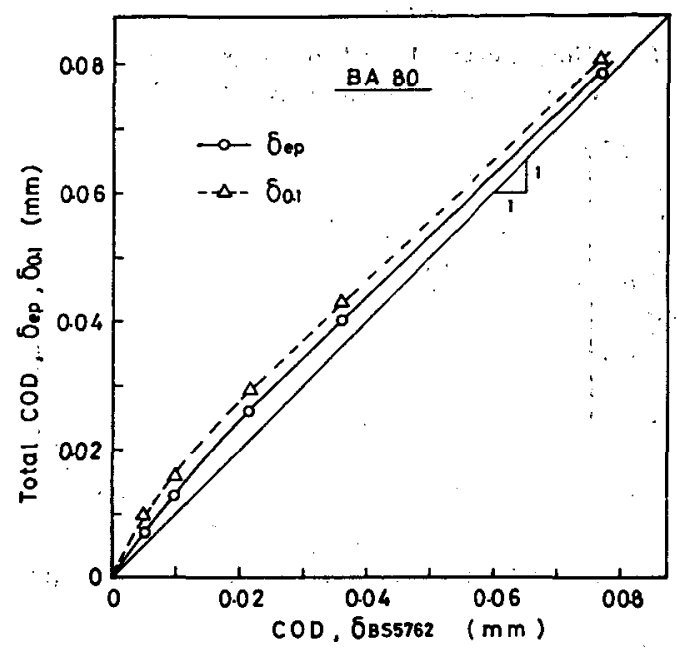

(b) in case of homogeneous notched-specimen subjected to bending.

Fig. 4 Comparisons of crack opening displacement $\delta_{\text {.p }}$ (COD at elasto-plastic boundary) and $\delta_{0.1}$ (COD at place $U .1 \mathrm{~mm}$ apart from crack tip) defined in the present paper with $\delta$ Dugdale (COD obtained from Dugdale model) or with $\delta_{\mathrm{BS} 5762}$ (COD specified in British Standard BS5762).

力学的不均質性を有する継手においてす，同様にして 母材部, 溶接金属部それぞれに対して $\delta_{\theta \rho}{ }^{B}, \delta_{e p}$ ॠを定 義すれば, き裂先端 $\mathrm{COD}, \delta_{e p}$ は $\delta_{e p}=\delta_{e p}{ }^{B}+\delta_{e p} W$ で求めることができる。一例として Fig. 5 に TA 80-60 の場合について示す，(a) 図は，切久き先端近傍の開口変 位形状を負荷段階どとに示したあので，低強度側にあた る溶接金属部での開口変位量は母材部側よりもかなり大 きく，開口挙動の非対称性が顕著に表われている，図中 の一点鎖線と実線との交点がその負荷時の弾塑性境界を 示してお゙り，母枋側と溶接金属側とでは切欠き先端近傍 の塑性変形の進行に明らかな差が認められる。前述した $\delta_{e p}{ }^{B}, \delta_{e p}{ }^{W}$ はこの弹塑性境界楾と各負荷段階における 開口変位曲線亡の交点での開口量として求められる。 のようにして求めた $\delta_{\theta p}{ }^{B} ， \delta_{\theta p} W$ およびき裂全開口量 


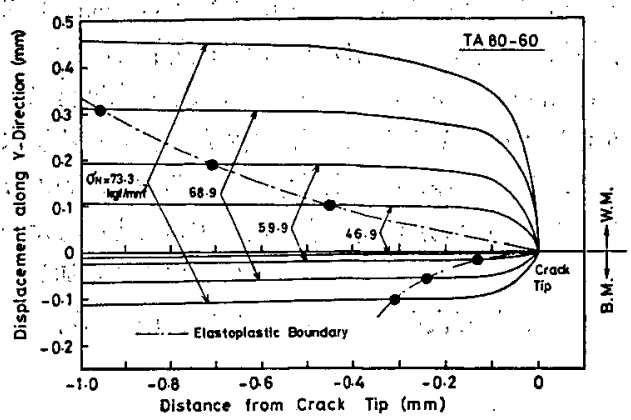

(a) Unsymmetrical crack opening in the vicinity of crack tip and elasto-plastic boundary.

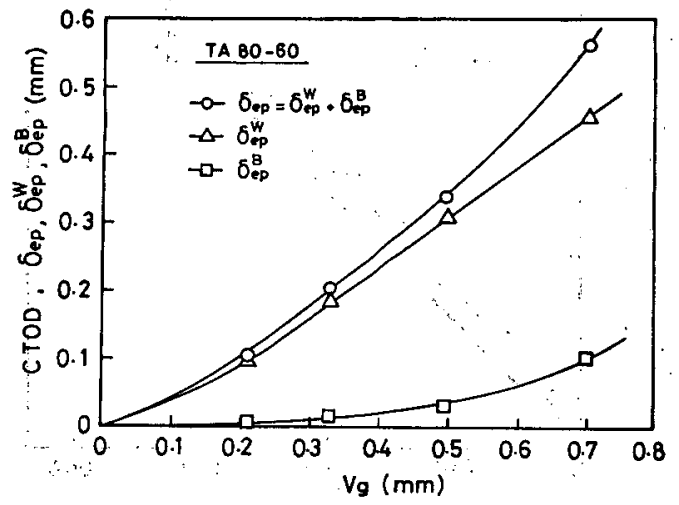

(b) Relation of total CTOD, $\delta_{e \phi}$ and local CTOD, $\delta_{e p}^{B}$ (on base metal side), $\delta_{s p}^{W}$ (on weld metal side) versus global CODD $V_{\boldsymbol{g}}$ at the center of notch.

Fig. 5 Crack opening behaviors of notched-plate with mechanical heterogeneity.

$\delta_{s p:}\left(=\delta_{e p}^{B}+\delta_{e p}\right)$ と切欠き中央の位置の開口量 $V_{g}$ との関係を示せば Fig. 5-b のようになる。

以上のととから, 変形の進行段階の指標として COD を用いるとすれば, Total GOD, $\delta_{s p}$ は力学的不均質性 を有する切欠き材では意味をあたないととが若えられ

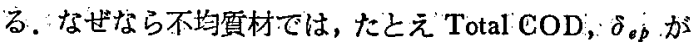
が同一であるとして6：不均質度合によって $\delta_{\theta p}$ W $\delta_{e p}{ }^{B}$ の割冾が異なるためである。したがっててのよう な材料究は，Total COD よりもむしろ，切灾き先端近 㥬の変形挙動をふまえた局部的な $\mathrm{COD}, \delta_{\theta \dot{p}}{ }^{n}, \delta_{i j} W K$ 注目することが重要であるといえる。

Fig: 6: は, Total COD; $\delta_{e j}$ 亿占める $\delta_{e p}{ }^{B}$ ¿ $\delta_{e p} W$ の割合が降伏強度比 $S$ r Kようてどのように影響さ机る かを見たものである：図中の横軸汶して $45^{\circ}$ の直線は 均賲材 (TA:80) の場合の片側の COD の值に対応す:る あのを示しており，中空町が母材側の Local COD;

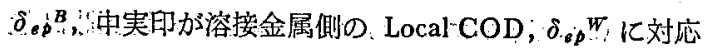

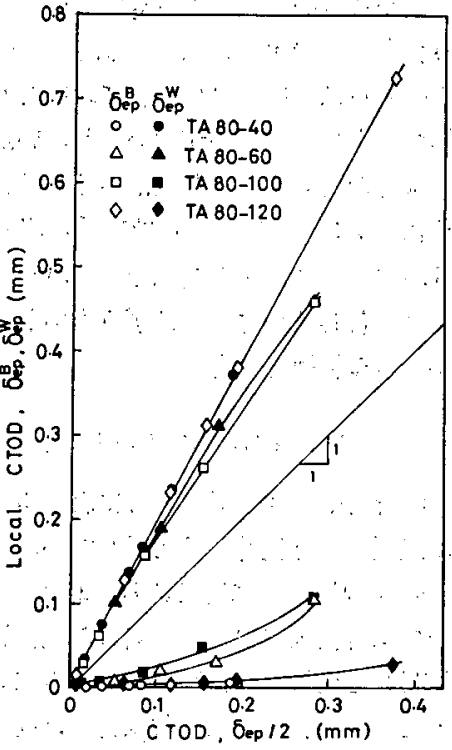

Fig. 6 Effect of mechanical heterogeneity on local GTOD, $\delta_{e p}^{B}, \delta_{s p}$-total CTOD $\delta_{e p}$, relation.

している，同一の $\delta_{\sigma \rho}$ 论注目してみると，低強度側の $\delta_{c p} l o c a l$ は高強度側の降伏応力との比が大きい程大き くなる傾向们あるあのの，その影響は相対比で考元ると き解析範囲内ではそれほど大きくない，一方, 高強度側 の $\delta_{c p} p^{\text {local }}$ は降伏強度比 $S_{r}$ の影響を大きく受け, 強

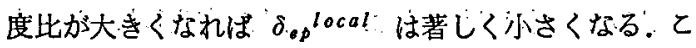
の上うに力学的不均質性を有する切欠き材で住 Total COD が同一です, Local COD， $\delta_{e p}^{l}$ local は降伏强度 比 $S$ ，の影響を受け，しがもその影響度は低強度側と高 強度側とでは異なるてとがわかる。この Local COD は 不均質材における変形挙動を記述する一つの有力な指標 となることが期待されるが，それには Local COD の評 価の仕方を一般化するととが必要となる，との点にうい ては次報において詳しく報告するととにする。

\section{5. き裂先端近傍の応力, 歪特性と Local COD}

前項で述べた Local COD が変形・破壊挙動の指標で あるためにはそれがき裂先端近傍の力学的状態の特異 性を支配するすのでなくてはならない，Fig.7、はT-type

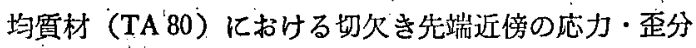
布特性を示したもので，(a) 図は相当塑性歪 (b) 図仙切欠き面化垂直方向 (荷重方向) 応力 $\sigma_{y}$ の分布 を示す，絞軸はそれぞれ降优歪 $\epsilon_{Y}=\sigma_{Y} / E$, 降伏応力 $\sigma_{Y}$ で無次元化しており，横軸はいずれす切欠き先端からの 距離 $r$ を各負荷段階におりる Total COD の半分 $\delta$ sp $/ 2$ で除して無次元化している，き裂先端の歪集中場の評価 


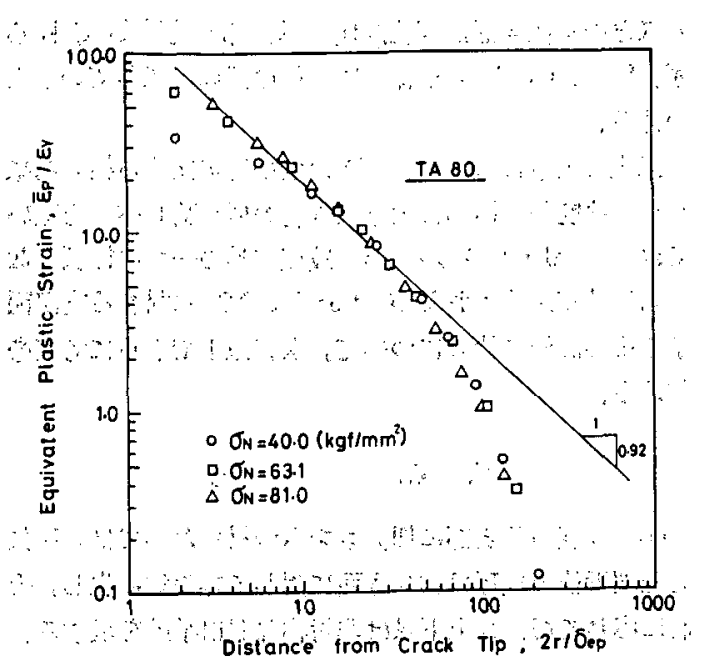

(a) HRR singulärity with reference to equivalent plastic strain $\bar{\varepsilon}_{p}$ :

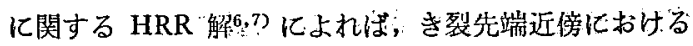
歪および応力の特䨢性は，(1)：式に示した電硬化則の場 合：それぞれ $r^{-1 /(m+1), r+n(n+1)}$ で表わされる： Fig. 7.をみると，切尔き先端近傍では負荷段階に然関係に;

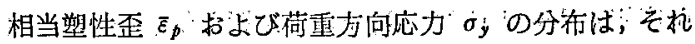
それ倾き $-1 /(n+1)=-0.92 ;-n /(n+1)=-0.08: 0$ 一本の直線でほ蛙犯せそうである。で傾向は曲げを

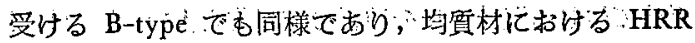
場の存在の確認ととも亿，均質材では Total COD,

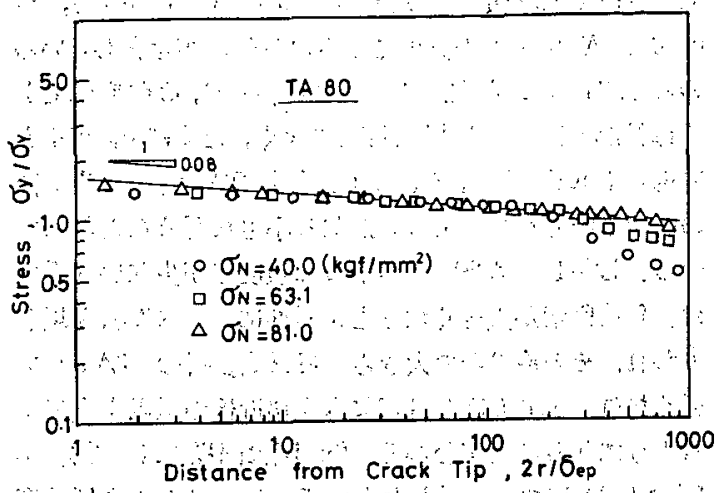

(b) $\mathrm{HRR}$ singularity with reference to vertical stréss $\sigma_{y}$

Fig. 7 HRR singularity in the vicinity of crack tip of homogenenus notched-plate.

が変形・破墑挙動に対する指標となり得るととがわか る.

二方; 力学的不均質性を有する㚬欠き材について同 様な整理を行えば Fig.8のようになる。たたし，Fig. 8 では；切矢き先端近傍の相当塑性歪 $\vec{\varepsilon}_{p}$ 分布を，母材側 亡溶接金属側とに区別して示しており；縦軸はそれぞれ の材料の降犾䄳 $\left(\varepsilon \xi^{B}\right.$ あるいは

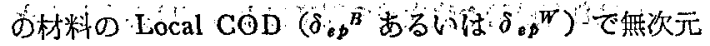

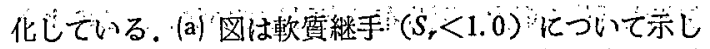
たすので, 低强度㒋でする溶接金属部の相当塑性歪分布 は；脑中には混乱するため表示してにないが，負荷段階

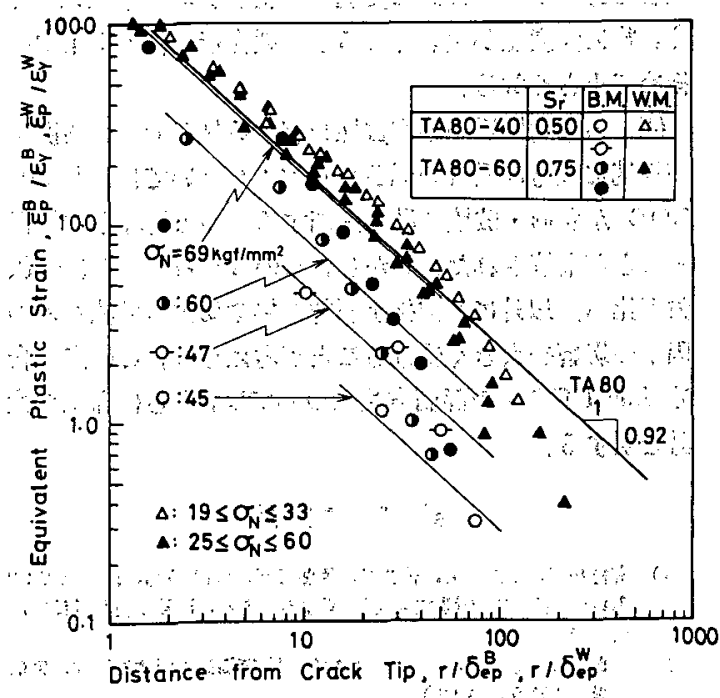

(a) Undermatchéd weld jöints

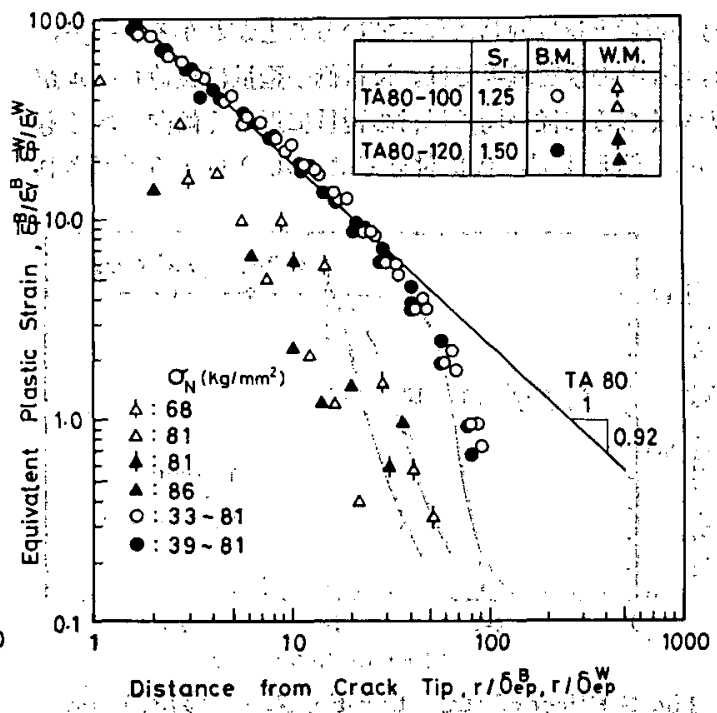

(b) Overmatched weld joints

Fig. 8 Equivalent plastic strain distributions in the vicinity of crack tipas function of the parameter $\left(r / \delta_{i p}\right)$, where $r$ is distance from crack tip and $\delta_{e p}$ is local COD. 
に無関係にほほ傾き-1/(n+1)=0.85(TA 80-40), = 0: 90 (TA 80-60) の直線で示される領域が存在し，いわ ゆる HRR 場の存在が認められる.。方, 高強度側であ る母材部では HRR 場は明膫でなく, とくに $S$ ，が小さ い場合P低負荷段階では，均質母材 (TA 80, Fig. 7-a 図 の直線と同じもの)よりもかなり小さな歪分布となって いる。しかし TA 80-60 のように強度差が少ない継手で は，負荷段階が大きくなると母材部认す HRR 特㬴場が 表われ，その特異場の大きさも母材均質材の TA 80 K 近くなり Local COD は切久き先端近傍の歪場を支配す るようになることがわかる。(b) 因は同様化硬質継手 $\left(S_{x}>1.0\right)$ について示したものである。 ての場合低強度 側となる母材部では，負荷段階によらず均澌母材（TA 80)とほほ同じ歪分布となっているととは注目される。

一方高強度側となる溶接金属部では，(a) 四の場合と同 様 HRR 場の存在は明瞭でく，負荷段階によっても歪 分布形状は翼なっている。

以上のととから，力学的不均質性を有する切欠き材で は，低強度側となる材においては HRR 場の存在が認め られ，Local COD がき裂先端近傍の応力・歪分布を支 配する力学的状態量となり得るととがかかる:一方高強 度側となる材では，塑性変形は大きく生じないで, Local COD は負荷段階や強度差の程度によっては必ずしあき 裂先端近傍の応力：歪分布を支配していない：てのよう なき裂先端近傍の雪分布におよぼす降伏強度比 $S_{r}$ の影 響を整理すると Fig. 9 のようになる; 縦軸は各継手の母 材側歪量と均質母材（TA 80）の歪量との比を表わして おり， $S_{r} \geq 1.0$ の硬質継手では，母材側の歪量は均質母 材の歪量と活ぼ同じになっていることがわかる。一方, $S_{r}<1.0$ の軟䨘継手では，母材側の歪量は負荷レベルが 大きくなるに従い均質母材の歪量に近うくく傾向にあるあ のの, 例えば $S_{r}=0.5$ 付近では, COD 量加予想され

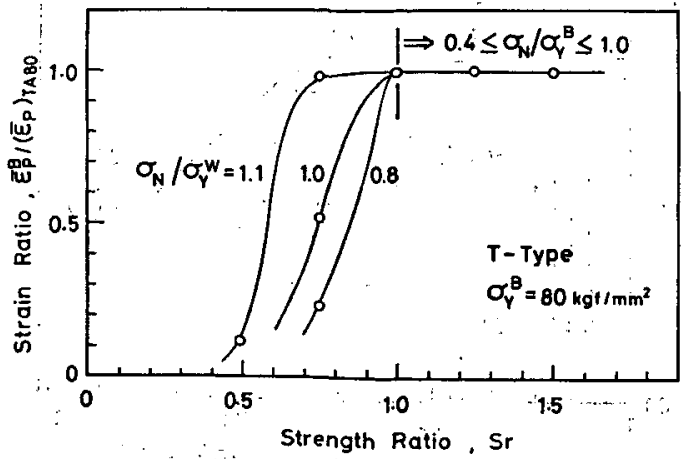

Fig. 9 Rffect of strength ratio, $S_{r}\left(=\sigma_{Y}^{W} / \sigma_{Y}^{B}\right)$, on strain of base metal in the vicinity of crack tip of overmatched/undermatched, weld joints.
るほどの塑性変形が高强度側の母材部で進行しておら ず，Local COD の指標性に今後の課題を残していると いえる.

以上のように Local COD の指標性に関する検討結果 から，強度差が極端に大きな場合の低負荷レベルを除い ては, Local COD が変形・破壊挙動の一つの指標とな る可能性が示焧されたが，Local COD に対する支配因 子やその評価の仕方について，次報以下でさらに考察を 加える.

\section{6. 結 論}

（1）強度の急変部に切欠きをあつ材においては，切久 き先端近傍の変形は切欠き面に対して非対称に生じ，そ れに応じて切欠き上下縁は非対称な開口挙動を呈する。 ての場合，たとえ Total COD が同一でも Local COD は，降伏強度比 $S_{r}$ の影響を大きく受け，てのために力 学的不均質性を有する材では従来の Total COD による 変形・破壊挙動の評洒手法は検討を要する。

（2）不均質材においては，低強度側での Local COD ば，相手部材との強度比が大きい程大きくなる傾向には あるものの，その影響はそれほぞ顕著ではない。一方高 強度側の Local COD は， $S_{r}$ の影響を顕著に受け; 強 度比が大きくなると Local COD は著しく小さくなる.

(3) ‘とのようなき裂開口挙動の非対称性は；き裂先端 近傍で生じる塑性変形の進行の非対称と大いに関連して いると考えられる，すなわち，低強度側では塑性変形の 先行と拡大が認められ，き裂先端近傍における歪集中が 顕著であるが，一方高強度側では塑性変形が生じにく く，特に強度差が大きくなるとき裂先端近傍の歪集中は 極めて小さくなる。

(4)：力学的性質の不均質性を有する材料では, 強度差 が極端に大きな場合の低負荷レベルを除いては，Local COD 肪変形・破填挙動を評価する一つの指標之なり得 ることが指摘された. しかし，この Local COD は降伏 強度比 $S_{r}$ 以外飞あ溶接金属部の幅や切欠き寸法などの 因子の影響を大きく受けるととが考元られ，ての点す含 め Local COD の評価方法については,さらに詳細な検 討を要する.

\section{劫考文献}

1）有持和茂，中西陸夫，佐萑進，佐藤邦落，豊田 政男，南二三吉：9

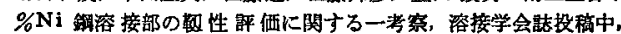
(1982)

2）豊貞雅宏：船用 LNG：タクの安全性評価法に関する研究, 東京 大学博土唃文，(1975)

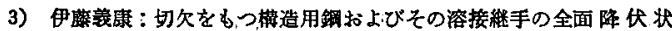

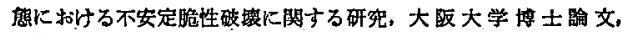
(1979)

4) C.E. Turner: Methods for Post-yield Fracture Safety 
Assessment Post-Yield Fracture Mechanics (ed.. by D. G. H. LATzKo) (1979)

5) Methods for Crack Opening Displacement (COD)

Testing. BS5762, (1979)

6) J.W. Hutchison : Singular Behaviour at the End of a
Tensile Crack in a Hardening Material, J. Mech. Phys. Solids, 16,(1968), 13

7). J.R. Rice and. G: F. Rosengren : Plane Ștrain Deformation Near a Crack Tip in a Power-Law Hardening Material, J:'Mech. Phys. Solids, '16, (1968), 1

\title{
9\% Ni 鋼溶接部の破壊挙動の特異性とその評価*
}

\author{
渡邀 之**, 鈴木 元昭**, 小谝，敏文** \\ Characteristic Fracture Behavior of $9 \%$. Nickel Steel Weldment*
}

by Itaru Watanabe**, Motoaki Suzuki** and Toshifumi Kojima**

The available data on the brittle fracture initiation properties of $9 \%$ Ni steel weldments bear out their satisfactorily high toughness at low temperatures, but have a little anbiguity that arises in connection with the pop-in fractures and the tendency of HAZ cracks to deviate into the lower strength ductsle weld metal which are observed when conducting fracture toughness tests on $9 \% \mathrm{Ni}$ stecl. weldments at low temperatures. However, no basic concept by which to assess the significance of such fracture behavior has been established yet.

With this fact in mind, and investigation was undertaken in order to arrive at a more precise interpretation of the correlation between a such fracture behavior and structural intergity of $9 \% \mathrm{Ni}$ steel LNG storage tanks. Three-point bending COD tests using coil-spring loading equipment and wide plate tests were performed on $9 \% \mathrm{Ni}$ steel weldments made using the austenitic Ni-based and matching ferritic. fillers. In these tests the pop-in behavior was also observed to some extent at $-196^{\circ} \mathrm{C}$, and the tendency for elimination of pop-ins by precipitating complete failure was predominantly observed at the same level of stress intensity in COD terms. It was nevertheless shown that $9 \%$ Ni steel weld-HAZs had no doubt satisfactory toughness at the LNG temperature $\left(-162^{\circ} \mathrm{C}\right)$.

\section{1. 緒 …兴}

最近になって LPG P LNG 等の液化ガス眝槽の建造 にあたって; 町㖆の構造の変更,ないしは脆性亀裂伝播 停止特性に基づいた材料選択の必要性が強く主張されて いる(-3)。このうち後者は局部に脆性亀裂が発生したと しても，龟裂の成長過程の早い段階でその伝播を阻止 し，それ认よって眝槽が全体破壊に至る危険を回避しよ うとするあのである。 そうした背景から，“最近 LNG 貯 槽用材料である $9 \% \mathrm{Ni}$ 鋼认ういても，脆性亀裂伝播停 让特性を評価しようとする実験的検討が広く行われてい $3^{4,5)}$.

しかしながらてれまでに公表されている多くの実証的 研究6.7)によれば，9\% Ni 鋼とその溶接部はいずれも十

\footnotetext{
*原稿受付昭和57年9月 2 日（全国大会論文発表䛾演）

**正 目 日本制管(株)技街究所 Member, Nippon Kokan

.. $\therefore$. K. K. Technical Research Center $\vdots$.
}

分な鞄性を有していると結諭されており，使用条件下で LNG 貯槽飞脆性亀裂が発生する危険な事態は予測し 得 ない.

しかしながらそれらの結諭に至る過程では,。なお解決 すべき問題点が残されている。:その一に, $9 \% \mathrm{Ni}$ 鋼溶接 部を対象とする破壊靯性試験に゙おいて,しばしばその発 生が確認されているポップイン破壊とその評価の問題が ある.9).ポップイン破壊は, 試片が最終破断に至るかな り以前の段階で, 予切欠の先端に锁小な胣性亀裂が発生 し，ごく僅かの距離伝播した後停止する現象をいう。こ のポップイン破壊については脆性莗裂が停止する理由が 不明確である他に，ポップイン破壊後最終破断に至る過 程が一様でない等現象的に複雑であり；その評価基準が 末だ確立されていいい。またポップイン破壊はしばしば 応力の低下をともなう ${ }^{10)}$. 乙れは微小龟裂の発生にとも なう瞬時的な変位の増大汇試験機, 試験片を含む系が適 